\title{
From Theory to Practice: Engaging Immigrant Parents in Their Children's Education
}

\author{
Judith K. Bernhard
}

Ryerson University

digital.library.ryerson.ca/object/358

Please Cite:

Bernhard, J. K. (2010). From theory to practice: Engaging immigrant parents in their children's education. Alberta Journal of Educational Research, 56(3), 319334.

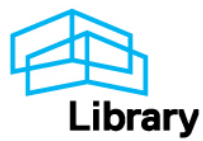




\author{
Judith K. Bernhard \\ Ryerson University
}

\title{
From Theory to Practice: Engaging Immigrant Parents in Their Children's Education
}

\begin{abstract}
The development of a series of theoretically based interventions for newcomer (immigrant) parents was undertaken over a 10-year period through an iterative method of designing and analyzing a series of ethnographic studies of its implementation. The results of three such interventions are reported here. The work was based on the critical theory of Freire and the post-Marxist and radical theories of Bourdieu and Cummins. Specifically, the interventions were designed to help immigrant groups of parents (of Latino origin) to understand their position of marginality, to help empower them, and to provide them with a basis for acting in support of their children's education in the new host country. The findings of the interventions reported show how the research program evolved along with the dialectic refinement of practice and theory.
\end{abstract}

Nous avons entrepris le développement d'une série d'interventions à base théorique visant les parents nouvellement arrivés (immigrants) au cours d'une période de 10 ans en employant une méthode itérative pour concevoir et analyser une série d'études ethnographiques portant sur sa mise en œuvre. Nous faisons état des résultats de trois de ces interventions. Le travail reposait sur la théorie critique de Freire et des théories postmarxistes et radicales de Bourdieu et Cummins. Plus précisément, les interventions ont été conçues pour venir en aide à des groupes spécifiques de parents (d'origine latino) en les aidant à comprendre leur marginalité, en les rendant autonomes, et en leur fournissant les bases pour être en mesure d'appuyer l'éducation de leurs enfants dans le nouveau pays hôte. Les résultats des interventions étudiées indiquent l'évolution du programme de recherche au fur et à mesure de l'amélioration de la pratique et la théorie.

\section{Introduction}

Basic changes in the early childhood education system have been extremely challenging to bring about. The inequities of power are firmly established and omnipresent. Indeed, these tend to be pervasive, invisible, and based on takenfor-granted assumptions. Postfoundational theories (e.g., feminist, postfeminist, post-Marxist, postcolonialist, critical) have been especially strong in clarifying underlying processes and the dynamics of the educational system including its violence (Bourdieu, 1986) to those of certain classes and social status. The immigration situation is particularly useful as an illustration of the types of oppression that exist.

Some of the basic facts that call for these new approaches are as follows. Particular immigrant groups, especially those of Latino or African background, have overall done rather poorly as specifically evident in the children's performance in the North American educational system. The dropout rate is a crude

Judith Bernhard is a professor in the Faculty of Community Services and Director of the MA program in Early Childhood Studies. She has investigated the effects of migration on family functioning. 
but well-known indicator of both disadvantage and fundamental disengagement.

Beginning in the 1960s, mainstream institutions undertook to address the problems of immigrants and the so-called "urban underclass." Most were extremely limited in their success, and the best results were achieved only by structuring the entire day and place of residence of the students.

However, there has been an explosion of theoretical developments connected with continuing oppression found in prosperous and otherwise "advanced" societies. These have focused on the power relations of the social groups involved and have brought to light a number of crucial assumptions and questionable propositions about immigrant parents and students as they fare in the educational system (e.g., "you can expect the kids to fail because the parents simply don't care"').

Our research team over the past decade has been addressing these problems and published the following reports among others: Bernhard et al. (2006); Bernhard, Freire, Pacini-Ketchabaw, and Villanueva (1998); Bernhard, Winsler, Bleiker, Ginieniewicz, and Madigan (2008); Garcia (2008); Pacini-Ketchabaw, Bernhard, and Freire (2001); and Pinkus (2008). The intention of this article is to summarize the data collected by these research teams and specifically to relate them to our developing theories and revisions of practice. I begin with a summary of background information on Canadian immigration and immigrant students in the educational system. Then follows a theoretical review. The following and major portion of the article looks in detail at a series of three interventions with parent groups. These illustrate the process of dialectic refinement of theory and practice. I briefly indicate at the end of each section where the practice worked, where it needed to be improved, and what refinements of theoretical ideas were desirable. The concluding section provides thoughts about moving forward.

I wrote this article in the hope of stimulating further dialogue. Much remains to be clarified and accomplished in the field. Our research teams over the years have been challenged to deal in concrete ways with the realities of power as discussed in the literature; we have learned how to listen better and talk to immigrant parents in specific ways that will assist them in resisting subordination.

\section{Background Information on Canadian Immigration and Students in the Canadian Educational System}

Immigration is transforming urban centers worldwide. More than 191 million people live outside their home countries according to recent figures (United Nations, 2007). As world economies continue to undergo changes, migration levels are likely to increase further. Internationally known for its multiculturalism policy and humanitarian reputation, Canada accepts over 260,000 newcomers every year.

Depending on the neighborhood of a major city, "new Canadians" may constitute $80-95 \%$ of the pupils, with new students coming in every day. Yet academic performance in Toronto, where almost $50 \%$ of residents were born abroad, provides a stark example of the outcomes of current arrangements. There is compelling evidence that children from some immigrant groups including Latino, African, and Portuguese continue to have lower academic 
achievement and higher dropout rates. At 39\%, the dropout rate for Spanishspeaking Toronto high school students is almost double the average for English-speaking students. Only 10\% of Latin Americans in Toronto graduate from university (Anisef, Brown, Phythian, Sweet, \& Walters, 2008; Bernhard, 2009). Although more than $36 \%$ of these come from economically disadvantaged families, the Canadian situation appears to be consistent with an international pattern. The 2006 PISA study of educational performance in 57 countries reported the widespread achievement gap of immigrant children (Organization for Economic Cooperation and Development [OECD], 2006; Statistics Canada, 2007a).

Several factors have left Canadian teachers largely ill equipped to interact effectively with immigrants. Whereas earlier immigration waves to Canada were characterized by people from Europe and Commonwealth countries with closer cultural and racial matches between teachers and immigrants, recent shifts in Canadian immigration policies have meant that newcomers are now more likely to come from Asia, Africa, and Latin America. Although one of every six children under age 14 in Canada is a member of a visible minority group (Statistics Canada, 2007b), Canadian teachers, predominantly white Francophones in Quebec and Anglophones outside the province of Quebec, are often unaware of the extent to which cultural differences affect students and their families. Despite the best intentions of boards, teachers, and school administrators to account for the disparity between combined teacher-parent objectives and the large numbers of immigrant children meeting with academic failure, one needs to pay attention to social structures, perceived groupings, and their power or lack of it. The challenges faced by newcomers to Canada have been the focus of a number of studies (Bernhard, Landolt, \& Goldring, 2009; George \& Michalski, 1996; Goldring, Berinstein, \& Bernhard, 2009; Lo, Preston, Wang, Reil, Harvey, \& Siu, 2000; Murdie \& Teixeira, 2000; Ng, 1993; Ng \& Ramirez, 1981; Siemiatycki, 1998). Although immigrants feel angry and shocked at the unexpected chilly reception climate, hundreds of thousands continue to make their children's future their priority.

Work with immigrant parents of children of preschool and elementary years has brought to light multitudes of examples of encounters with institutional obstacles, cumbersome procedures, and teachers' ignorance or assumptions about the supposed superiority of advanced Western cultural norms and capital. To give the simplest of examples, the communications from school to parents including report cards are often incomprehensible despite any translations that might be provided. As well, they tend to disempower the recipient utterly (e.g., "we consider it in the best interest of your child to enroll him in a special needs program"). The parents may see a prize when in fact it is a sentence to academic failure.

There is much literature that I do not review here about preconceptions that are applied to immigrant children ranging from "spoiled and clinging" to "disruptive" and "like a wild animal" (Bernhard, 2004; Bernhard \& Freire, 1996). Below I turn to a discussion of the theories on which our interventions were based. 
Theoretical Frameworks and Other Interventions

Critical pedagogy. A main underlying theory for our work is the work of radical educator Freire (1999), who worked to empower oppressed communities in Brazil, a clearly postcolonial situation. Freire believed that the oppressed should not be marginal, nor should they live outside society. His solution was not to integrate them, but rather to transform the entire structure. He suggested that an educational program would be successful only when it began at the grassroots level and used a collaborative problem-solving model rather than a "banking" model wherein information is deposited in students.

Freire (1999) held that the interaction between teacher and student did not occur in a vacuum, but rather in an elaborate social context in which the pupils did not passively reproduce the information presented to them. By empowering students and using cultural references, he tapped into sources of strength and ideals. For example, when Freire worked with peasants to teach them to read, he found that in order to be effective, the learning opportunity needed to be experiential and emotionally engaging. Freire's insight was to start with the position of the people themselves and their understanding of it. Further, he emphasized the importance of their coming to see that legitimate structures were not set in stone, but could be challenged and altered.

The point of departure of the movement lies in the people themselves. But since people do not exist apart from the world, apart from reality, the movement must begin with the human-world relationship. Accordingly, the point of departure must always be with men and women in the "here and now ..." To do this authentically they must perceive their state not as fated and unalterable, but merely as limiting and therefore challenging. Whereas the banking method directly or indirectly reinforces men's fatalistic perception of their situation, the problem-posing method presents this very situation to them as a problem. (p. 66)

In summary, learners are learning to take charge of their own lives and acquiring a sense of agency. In this manner, they gain power in their situation and the ability to alter their circumstances.

The change process that learners both undergo and take charge of shows particular features to which I draw attention. In particular, Freire (1999) stressed the regaining of one's humanity through redressing violations that have occurred in the social processes.

Resignation gives way to the drive for transformation and inquiry, over which men feel themselves to be in control. If people, as historical beings necessarily engaged with other people in a movement of inquiry, did not control that movement, it would be (and is) a violation of their humanity. (p. 66)

His teaching method strongly relied on discussion and dialogue rather than repetition and memorization. Such dialogue allows for the development of joint responsibility:

Through dialogue, the teacher-of-the-students and the students-of-the-teacher cease to exist and a new term emerges: teacher-student with students-teachers. The teacher is no longer merely the-one-who-teaches, but one who is himself taught in dialogue with the students, who in turn while being taught also teach. They become jointly responsible for a process in which all grow. (p. 61) 
The format and the content were both important. For example, Freire began one lesson with the letter $O$ to allow the peasants to discuss the word oppression and how this term explained what had initially seemed like individual experiences of poverty. The specific, well-thought-out topics with which he began his lessons mattered deeply to the students and gave them the motivation to learn to read in order to understand how their individual problems were in fact part of systemic issues that led to their marginalization. The process of becoming conscious of their place in the system was labeled conscientization, or conscientização (Portuguese). Freire's methods are outlined in The Pedagogy of Hope (1994), a book that has inspired educators worldwide to encourage their students to read the world through the word.

Cultural capital. The second theory on which we have relied to develop our work was that of post-Marxist, social theorist Bourdieu (1986). He has deepened our understanding of power and its mode of operation. He saw power as diffused in institutions and everyday practices of society (Cannella, 2002; Corson, 1998; Looker, 1994). Without being aware of it, the individual is highly constrained by these practices and has lost any vision of alternatives available to him or her. Based on Bourdieu (Lareau, 1989), we have employed the concept of cultural capital, which is defined as those dispositions (habitus) and capabilities that establish a person of a particular background and social stratum in a set of social relations through which relationships he or she produces and reproduces his or her own socially constructed position.

An example given by Bauder (2008) is as follows: a person's passport can function as a form of cultural capital. It is a signifier, a mechanism that gives those who have it the capability to tap into employment opportunities, professional recognition and so on. Those who are not given such citizenship tend to be vulnerable or exploitable. Bauder goes on to explain the subtle ways that members of the elite group show their status:

\footnotetext{
Bourdieu suggests that the members of an elite social group may signify their status through embodied cultural capital in the form of subtle "gestures or the apparently most insignificant techniques of the body-ways of walking or blowing one's nose, ways of eating or talking." In this case, those who do not possess the code to read or enact these cultural performances lack access to important symbols of power. Another process of distinction exists in the form of institutionalized cultural capital represented by educational diplomas, certificates or other types of institutional acknowledgment. (p. 318)
}

In accord with Bourdieu and Bauder, we see ethnicity not as an inherent group characteristic, but primarily as an ongoing ascription and construction by those constituting themselves as the dominant group(s). In other words, immigrant can be viewed as a construction of official discourse, and his or her deficits follow as a matter of course. The same arguments generally applied to race categories (Darder, Torres, \& Gutierrez, 1997; Dei, 2001) as well as those of class and nation of origin. These are key concepts that we have used from postfoundational theories.

Many educators have said that they are frustrated at the lack of response on the part of newcomer families. They say, with some justification, that the parents are not involved; they do not come to meetings and do not seem to have the motivation or to show an interest in participating in their children's 
schooling. What teachers call immigrant parents' lack of motivation and interest can be said to be an expression of the dynamic of their devaluation. Thus the teachers' ability to facilitate their students' success is undermined by their lack of understanding and valuing of the cultural capital that immigrant parents bring.

An important and related concept is that of funds of knowledge developed by Moll (González, Moll, \& Amanti, 2005) to identify bodies of knowledge and know-how that are "historically accumulated" and circulated in marginalized communities and come to act as resources that are "essential for household or individual functioning and well-being."

The devaluing of immigrant parents' cultural capital is further exacerbated by educators' preservice training in the age-stage theories prevalent in the field of child development that portray childhood as a fairly narrow range of ages and stages without accounting for discrepancy of background. Although it is now increasingly recognized that milestones of childhood and definitions of optimal development are diverse and culturally dependent (Bernhard, 2003; Bernhard et al., 1998; Garcia Coll, 1990; Hedegaard, 2009; Lerner, 1988, 1991; O'Loughlin, 2009; Onchwari, Onchwari \& Keengwe, 2008; Rogoff, 1990), immigrant children growing up with a different set of priorities than that of the educational system are often construed as behind and needing to catch up with their age-mates. Teachers, therefore, miss the many other ways that these children demonstrate strength and competence. Rather than turning to parents for information about their childrearing goals in order to assess correctly their students' development, newcomer families' cultural capital and unique "funds of knowledge" (González et al., 2005) are often invisible or devalued by teachers.

Identity, engagement and community. The third theory on which we have drawn in our work is that of Cummins $(1989,2001,2002)$, a critical theorist with a focus on bilingualism and biculturalism (see also Ada, 2003; Corson, 1998; New London Group, 1996). This focus has been on connections between developing a positive identity and increased academic achievement. Nurturing a student's identity involves not only recognizing the forms of prior knowledge (including home languages) that he or she brings to the class, but also incorporating them into classroom learning (Cummins). Insight into students' home environments and cultural contexts provides ways of understanding how children make sense of their world (Taylor, Bernhard, Garg, \& Cummins, 2008; Westby \& Atencio, 2002). When educators direct their efforts toward learning and understanding how children experience the world, and when they strive to become familiar with the complex context (including culture and language) in which students, educators, and families live and learn, they are better equipped to respond to students' needs and concerns (Artiles \& Klingner, 2006; Klingner \& Artiles, 2003). By cultivating an optimal learning environment-instructing a child in his or her first language, using a child's prior knowledge and personal experiences-educators and school personnel can provide greater opportunities for immigrant students to achieve academic success.

Language is one of the strongest elements in one's self-definition as an individual and a social being. Attending to and valuing a child's home lan- 
guage in the school context is an important way to show respect for the child and his or her family, community, and culture. All children have the right to retain, develop, and enrich their heritage language while learning a national language. Retaining one's own language offers many more opportunities for human growth and certainly creates greater opportunities to work on behalf of humanity (Cummins \& Sayers, 1995; Fishman, 1989; Krashen, 1999).

The focus on language involves promoting not just explicit knowledge of how the linguistic code operates, but also critical awareness of how language operates deep within society.

Cummins' (2002) theories recognize that students' position in relation to the teacher, to other students, and to the learning community is the basis of identity investment and overall engagement, in particular cognitive. Learning is optimized when these interactions maximize both cognitive engagement and identity investment. Teacher-student interactions and other interactions in the learning community (including the classroom, the school, the family, and broader community, and virtual communities enabled through electronic communication) create an interpersonal space where knowledge is generated, identities are negotiated, and agency is developed.

To draw these threads together, the theories of Freire, Bourdieu, Cummins, and others have proposed a number of key concepts, among them empowerment and agency, oppression in mainstream institutions, marginalization, cultural capital, linguistic dominance, and personal identity as negotiated by disadvantaged groups. All have proposed ways of challenging the structures that are in place and considered to be authoritative. In a broader sense, the theories challenge the foundations of the normative theories of child development and immigrant adaptation.

Using these theories, besides aiming for critical development of knowledge, our research projects were also meant to help empower immigrant groups. Specifically, we have focused on efforts to identify, analyze, and help overcome school difficulties by forming a special parents' group based on similar ethnic background and facilitated by native speakers of the parents' home language. We saw the parents' experiences as reflecting inequitable social structures, but also as a basis for action to change problematic situations. The following section provides an account of our interventions.

\section{The Eight-Month Parent Group Intervention}

A 1995 grant from the Canadian federal government allowed us to work with a group of 12 Latin American parents, primarily mothers, over an eight-month period (Bernhard, Freire, Pacini-Ketchabaw, \& Villanueva, 1998). Monthly discussions about aspects of their children's experience with Canadian schools took place at a Toronto community center. Participants had been recruited through word of mouth, television, and newspaper features. The solicitation did not require or presume that the children were experiencing academic difficulty.

One way that the researchers established their credibility with the Latin American parent group was their shared Latino background. One of the leaders for the parents' group had completed her medical studies in Chile and moved to Canada where she completed postgraduate training in psychiatry. She was at the time a school board chief psychiatrist. The other group leader 
had lived in Chile until 16 years of age and had moved to Puerto Rico and then to Canada. On receiving her doctorate, she became a professor in education. Because the two researchers leading this group were seasoned professionals who had extensive knowledge of the Canadian educational system, they were easily able to answer all the parents' questions.

Our facilitators' opening invitation to parents was in line with Freire's views as a humanist, revolutionary educator. The parents were enlisted as partners who assumed their full role as empowered human beings.

The role of the facilitator was not as a dispenser of banked knowledge. Rather, she invited an alternate dynamic by initiating discussions with neutral, open-ended questions, giving parents a clear message that the topics of focus would be close to their reality and that the discussions would be meaningful rather than static and alien to their experience.

On a rotating basis, group members acted as co-facilitators and assumed responsibility for ensuring that the discussions were orderly, also reflecting Freire's problem-posing theoretical framework where the roles of teachers and students are fluid and their relations dialogical. This process illustrates the joint responsibility to which Freire referred, quoted in my review above. One participant described her experiences of these novel arrangements.

In the first place, the dynamism, the mutual trust, that I was given, I felt very sure of myself, I felt that this is my place ... I had a lot of freedom to express so many things ... So that is what I liked and really caught my attention ... I did not want to miss even one meeting and even with my work, I made every effort to come and I didn't want to miss even one moment of the class.

With the goal of empowerment, facilitators encouraged participants to comment on interpretations of their previous statements by summarizing the topics discussed in previous sessions and asking the participants whether they wanted to elaborate on those topics or discuss other issues. In this way, participants were helping to take charge of their own process. Further, this approach allowed facilitators to reevaluate their reflections and plans.

Families began to gain each other's trust and identify barriers to their involvement in the educational system, some including issues of sex, race, and class. The parents engaged in dialogue, posing problems they were encountering, and with the help of the facilitators and the other parents, developed a deepened consciousness of their situation including potentially transformative actions such as how to take action to transform their initial feelings of not being welcome when they entered the schools. This dialogic method was also intended to resonate with Freire's writings on the movement away from banking education.

In analyzing the results of this first phase, we realized that the parents now knew that there were policies encouraging parental participation, that they could challenge the labels of deficiency that they were being assigned, and could even act in resistance to the institutional procedures of mainstream schooling. We had successes in several important areas as mentioned above; for example, increased occasions where the parents attended parent meetings at the school and knew that they were expected to take an active role in the children's education. 
We discovered that because of the frequent marginalization of newcomer parents, it was important to show them that they had little to fear and much to gain by being actively involved.

In a number of cases, the parents did not agree with the decisions of the school and felt frustrated at not being able to shape decisions about their children. The consequences of these missteps were readily evident in the Latino parents whom we interviewed, who noted that the Canadian teachers speaking as experts left them feeling unable to make their views known. Parents also noted that the jargon and specialized terms that educators used during meetings such as withdrawal, special education, below grade level functioning in English, and reading clinic were not understood even when translators were employed.

Our theoretical basis helped us to understand the objective features of marginalization, to see that the parents were unlikely to effect genuine and long-term changes without understanding and knowing how to contest the power structures involved. In the next intervention, we explicitly addressed the acquisition of such knowledge and how to exercise it. Our objective was to show parents that advocating on behalf of their children or expressing their legitimate complaints was their right, and that rather than producing ill feeling or retaliation on the part of the teachers, it would have a chance of being effective. This was seen as a means to our goal of empowerment.

We realized that despite the goodwill of all involved, the parents would not be able to bring about changes unless structures were altered to include recognition of their cultural capital, including, for example, two-way interactions wherein both sides listened and spoke. Parents needed some power to ensure that their ideas were given serious consideration and if possible acted on. Parents needed to learn how the system worked and what the codes of power were; and then act.

\section{The Parenting Workshops Intervention: Learning the Codes of Power}

In order to respond to the lessons learned in the first phase of the research, our research team worked to develop and pilot a 10-week project that was the basis of the parent groups that later came to be known as the Canadian Parenting Workshops (Bernhard, Freire, \& Mulligan, 2004). The intent of this intervention was to see if in addition to the parents being able to tap into their networks and know that their voices would be heard, they would also learn to see schools as sites for the reproduction of the social order: in Bourdieu's (1986) terms, to acquire the habitus that signifies they are part of the code of power.

The primary changes involved bringing forward dialogue on information about the important role of attachment across cultures and biases in the definition of terms such as developmentally appropriate or school-readiness. Also included in this second phase was information about school report cards, contacting school superintendents and members of parliament, learning about school committee structures, and the workings of the designation of children for the special education system.

In order to field test and evaluate the intervention, it was implemented in four community-based settings in Vancouver, Montreal, and Toronto in fall 2002 and spring 2003; all were Latin American parents of children aged 4-8. A total of 55 mothers registered for the program. Forty-eight completed the 
program and final surveys. Most of the mothers were in their mid-20s to late $30 \mathrm{~s}$, as might be expected for mothers of children from birth to age 8 . Family size was generally between one and three children. All the mothers and almost all the fathers were born in Latin American countries. Most had come to Canada recently: a large majority had been in Canada fewer than five years and half for fewer than three years.

In addition to being newcomers to Canada with young children, the mothers in the parenting groups were further isolated from the mainstream. Only one fifth spoke the languages of their children's schools. Nine out of 10 had incomes below the Canadian Low Income Cut-off. These parents had limited support for parenting - in addition to having left behind extended family members, a quarter were single parents, nearly half reported no help with their children, and one in 10 had no help or advice about parenting.

As the groups progressed, parents indeed began to interact with the school personnel, assert themselves, and know that their views would be heard. Mrs. Blanco said,

My daughter was enthusiastic about taking a trip for three days, so I paid for the ticket. But then she told me she did not want to go because she was going to feel alone and she had never been away from home. The principal told me that my daughter still had to go because I had already paid. So I said to him: "Excuse me, but I cannot do that. If my daughter does not feel good about going, I will not send her." I was firm and they gave me the money back. The group gives one more assurance to do what we think is right with our children.

Thanks to her experience with the group, this mother now knew that her views had validity. In Bourdieu's (1986) terms, this mother had become aware of her subordination in the institution and the role that her language played in it. Further, she had developed additional cultural capital, had learned how to tap into the codes of power and behave in ways that the school staff recognized as legitimate and valid. In this way, her frustration gave way to transformation. This mother's experience with the problem-posing methods derived from Freire $(1994,1999)$ enabled her to understand her marginalization and how the system worked if not challenged. She learned what actions she needed to undertake to affect the system and the outcome for her child.

Our analysis indicated that the group experience helped the parents to comprehend better what was expected of them in the support of their children's schooling while retaining their own cultural assets. Parents learned not only to collaborate with teachers and express their concerns, but also to affirm their ethnocultural differences. This came up several times in the area of discipline, with parents reacting to how the children's behavior was dealt with by the schools in Canada.

Mrs. Garcia's sister-in-law provided us with an example illustrating how a newcomer parent retained her cultural assets in an interaction with the school. Mrs. Rojas told us about her 14-year-old son Alfredo, who had misbehaved but later recognized his mistake and apologized to the school.

Alfredo was suspended from school. We went to talk to the vice-principal and told him that he [Alfredo] recognizes he acted badly, but not to suspend him because he was going to lose the school year. We asked if the child could do some volunteer work as a penalty. The vice-principal was totally against it and 
said that in this school there is no volunteer work. I am not justifying Alfredo, but how can they be so rigid?

Alfredo eventually had to repeat the semester, but was also sent to work with his father for two weeks-12-hour days, six days a week. The parents implemented their own volunteer work program.

Participants' satisfaction was evident in focus-group responses and in their attendance. An average of $85 \%$ of registered mothers attended each session, with over half of participants attending $90 \%$ or more of the sessions. Through their written and oral feedback, the mothers in parent groups affirmed the benefits of the intervention and its effect on their knowledge and behavior.

For example, mothers increased their use of informal and formal supports. They found ways to overcome the barriers and penetrate the school walls.

I decided I am going to start to get in the school and to bother teachers so much that they are going to listen to me. Now, I am there. And with all the parents there are, and if we all start to get into the school and make them listen to us, they will let us in. The other day, the teacher asked me to go to school to help children with their reading.

Mothers reported learning and using certain Canadian ways such as offering children more choices, taking time to explain consequences of various choices, and reading frequently while also consciously retaining their own cultural capital including such values as the emphasis on respect for elders, a focus on good manners, and a sense of the interdependence of family members.

By the end of this second phase, mothers also understood better how to communicate with teachers and principals, and more mothers agreed that it is important to share information about their culture with their children's teachers; they told stories about teachers' positive responses.

Yet parents often picked up on teachers' implicit and not so implicit cues about speaking Spanish in the home and began to speak to their children in English or French instead of their native language. As one Colombian mother recounted,

One day I told the teacher that I like speaking in Spanish with my daughter because I wanted her to learn both languages. The teacher answered me that I should speak in English and not in Spanish. She told me that she thought that I should speak to my daughter in English.

This mother understood that the school did not attach any particular value to her home language. The message that she received was that her knowledge and cultural capital were marginal to what was being taught at school.

Overall, the intervention enjoyed success according to several indicators. The parents developed an awareness of their social position, learned what cultural capital was, and came to understand the basis of their children's imminent marginalization. They learned what needed to be done in order to generate the desired responses from the teachers and the educational institutions generally.

However, the project brought to light problems in a number of areas. We had found that families' intentions and desires to maintain their mother tongue became overwhelmingly difficult to attain as they received little encouragement from dominant institutions. Practitioners' influence on parents' decisions 
and actions regarding their children's learning was shown to be enormous. For some of the mothers participating in our studies, feelings of insecurity and sometimes guilt led them to abandon the use of their mother tongue with their children.

We found the language issues to be especially clarified by the theoretical approaches described above. Language issues were a crucial structural constituent of the gulf between parents and children, as language heritage, as a rich emotional resource and carrier of an ideology associated with a particular view of the world was being lost.

For all these reasons, proactively working with parents to recognize and build on their own cultural capital, including their home language, became a priority for further interventions. We found it was crucial to have a clear focus on helping newcomer parents affirm their linguistic and cultural identity. In this way, rather than lose cultural capital, newcomer families would develop their own capital, tapping into their own knowledge resources and experiences as expressed in their own language to help their children succeed in school.

\section{The Parenting Circles Intervention}

The opportunity to revise the intervention further to include a focus on linguistic and cultural identity came in 2007, when with a grant from the Ontario Ministry of Education, a research team worked with a group of 11 parents in a six-week program that combined the Freirian dialogue and content of the program with a focus on identity formation and affirmation of cultural capital that involved parents writing books for and about their children.

In addition to the earlier goals of providing newcomer parents with relevant information about the local school system and how to access resources and networks of support in the community, we incorporated a creative bookauthoring element to encourage Spanish-language maintenance and the acquisition of a strong sense of self-worth and pride in cultural identity.

The Authors in the Classroom Program (ACP) was developed to improve the possibility of more equitable outcomes for all children. Originated by Ada and Campoy (2003), it was implemented at the early education level under the name Early Authors Program (EAP, Bernhard et al., 2006; Bernhard et al., 2008). The ACP/EAP incorporated a transformative literacy model in which parents and children self-authored books or "identity texts" about themselves, their families, and their goals. Scanned photographs and word-processing were used to create the books, which allowed parents to communicate and share their personal experiences.

The process of involving immigrant parents in self-authoring books, aimed not only at enrichment of their children's school readiness (in particular, print motivation and increased vocabulary), but also at strengthening links between and among children and their families. The process was geared toward the acquisition of a strong sense of self-worth and pride in cultural identity. The focus of the texts written by the parents was on affirming the linguistic and cultural identity of their offspring and covered such themes as This is Who I Am, the Story of My Name, A Special Person in My Life, and Hopes and Dreams for My Child.

The mothers came to recognize that the act of expressing their thoughts, feelings, and knowledge in writing had far-reaching benefits that they could 
not anticipate for their children and went beyond the immediate reaction they may have had. As the parents witnessed the positive feedback from their children, they began to fully comprehend how this was a new tool for positive communication. Marta eloquently concluded,

Another thing that I really liked was learning to make the books as a medium for family communication. It was a wonderful experience, and I will never forget it. My son saw the books and was stimulated, motivated and happy about the things that I communicated to him ... It is exactly the way to communicate with photos, designs, creativity, with written text, for our children, this type of written communication is what was really new for me.

Marta had been a French teacher in Ecuador, and she embraced this new form of communication with fervor, as did the other parents. Her identity investment was reflected in the books she wrote and shared with her children.

Before the start of the Parenting Circles intervention, the parents were asked to rate their goals and desires for their children for the next five years. Fluency in English, adaptation to the new environment, and academic success were the top three goals identified among the group, with adaptation and academic success seen as dependent on English fluency. By the end of the intervention, there was a heightened assertion and appreciation of the group's cultural heritage and recognition of the value of transmitting that heritage to their children. The factors of cognitive engagement and identity investment, central to Cummins' theory, were especially prominent.

These successes are qualified by our knowledge of the resistance of all systems to fundamental changes. The efforts over a period of weeks or months have to be part of a long and intensive process involving several years or decades in order to have a significant effect on the system.

\section{Carrying on the Work: Looking to the Future}

The significance of our work has been in providing parents with the tools to reach out to educators. Parents gained the confidence and skills to engage with their children's academic development and enrich their lives. The appeal of the project is that it can be implemented at no great cost and without the need for external support or extensive facilitator training. Any institution can implement a process of Freirian dialogue groups given the willingness to listen with sensitivity to parental concerns and basic training in the principles covered here.

All these processes were informed by our theoretical commitments. The theories I mention were crucial in highlighting how the interventions could be improved, especially with regard to oppression, agency, and development of cultural capital and personal identity.

When used again, the program could never be replicated exactly, nor should it be. Exact replication of the techniques and content of the program is not required, although fidelity to its principles certainly is. As we see it, the "package" is defined according to its basic principles; it does not depend on fine details of procedure or content. Even if particular procedures were outlined in detail, it would be inappropriate to transfer those specifications directly into another environment. 
An important point I make is about the value of research and evaluation in the development of the program. During each phase of our work, we have been guided by feedback obtained from both facilitators and participants. The consistent use of pre-post information collection from participants allows the revisions of theory and practice that we undertook.

Our contribution has been to provide support to newcomer parents to find their voice and make meaningful contributions to their children's academic success. Although the parents may not speak the language of the school, or may not have high literacy levels, they have much to contribute. Our drawing from several theories, especially postfoundational and critical ones as developed by Freire, Bourdieu and Cummins, guided and structured the process and pointed us to specific areas that needed to be addressed.

Yet the relevance of the work of the parenting interventions reaches beyond individual communities and their plights. We are living in turbulent times that discourage immigrants from challenging dominant institutions like schools. Social and educational institutions are subject to increased stresses. Crisis periods sometimes provide opportunities to address old issues such as the high dropout rate in new ways. As the theories on which we drew provided the tools that we needed then, they may in future inform continued efforts by these subordinated groups to achieve just outcomes in their new society.

References

Ada, A.F. (2003). A magical encounter: Latino children's literature in the classroom. San Francisco, CA: Allyn and Bacon.

Ada, A., \& Campoy, I.F. (2003). Authors in the classroom: A transformative education process. Boston, MA: Allyn and Bacon.

Anisef, P., Brown, R.S., Phythian K., Sweet, D., \& Walters, D. (2008). Early school leaving among immigrants in Toronto secondary schools. CERIS Working Paper, 67. Retrieved March 23, 2010, from: http: / / ceris.metropolis.net/Virtual\%20Library/WKPP\%20List/WKPP2008/CWP67.pdf

Artiles, A., \& Klingner, J.K. (2006). Forging a knowledge base on English language learners with special needs: Theoretical, population, and technical issues. Teachers College Record, 108(11), 2187-2194.

Bauder, H. (2008). Citizenship as capital: The distinction of migrant labor. Alternatives, 33, 315-333.

Bernhard, J.K. (2003). Toward a 21st century developmental theory: Principles to account for diversity in children's lives. Race, Gender, and Class, 9(4), 45-60.

Bernhard, J.K. (2004). The school "misbehavior" of Latino children in a time of zero tolerance: Parents' views. Early Years Journal, 24(1), 41-62.

Bernhard, J.K. (2009). Latin American students in the Toronto District School Board: Research findings and recommendations. In D. Mantilla, D. Schugurensky, \& J.F. Serrano (Eds.), Four in ten: Spanish speaking youth and school drop out in Toronto. Toronto, ON: Transformative Learning Centre, OISE/University of Toronto. [Also published in Spanish as Cuatro en diez available at http: / / fcis.oise.utoronto.ca/ lared/]

Bernhard, J.K., Cummins, J., Campoy, I., \& Ada, A. Winsler, A., \& Bleiker, C. (2006). Identity texts and literacy development among preschool English language learners: Enhancing learning opportunities for children at risk of learning disabilities. Teachers College Record, 108(11), 2380-2405.

Bernhard, J.K., \& Freire, M. (1996). Latino refugee children in childcare: A study of parents and caregivers. Canadian Journal of Research in Early Childhood Education, 5(1), 59-71.

Bernhard, J.K., Freire, M., \& Mulligan, (2004). Canadian parenting workshops. Toronto, ON: Chestnut.

Bernhard, J.K., Freire, M., Pacini-Ketchabaw, V., \& Villanueva, V. (1998). A Latin American parents' group participates in their children's schooling: Parent involvement reconsidered. Canadian Ethnic Studies Journal, 30(3), 77-98.

Bernhard, J.K., Gonzalez-Mena, J., Chang, H.N., O’Loughlin, M., Eggers-Pierola, C., Roberts Fiati, G., \& Corson, P. (1998). Recognizing the centrality of cultural diversity and racial equity: 
Beginning a discussion and critical reflection on "developmentally appropriate practice." Canadian Journal of Research in Early Childhood Education, 7(1), 81-90.

Bernhard, J.K., Landolt, P., \& Goldring, L. (2009). The institutional production and social reproduction of transnational families: The case of Latin American immigrants in Toronto. International Migration, 46(2), 3-31.

Bernhard, J.K., Winsler, A., Bleiker, C., Ginieniewicz, J., \& Madigan, A. (2008). Read my story: Promoting early literacy among diverse, urban, preschool children in poverty with the Early Authors Program. Journal of Education for Students Placed at Risk, 13(1), 76-105.

Bourdieu, P. (1986). The forms of capital. In J.C. Richardson (Ed.), Handbook of theory and research in the sociology of education (pp. 241-257). New York: Greenwood.

Cannella, G.S. (2002). Deconstructing early childhood education: Social justice and revolution. Rethinking Childhood 2. New York: Peter Lang.

Corson, D. (1998). Changing education for diversity. Philadelphia, PA: Open University Press.

Cummins, J. (1989). Empowering minority students. Los Angeles, CA: National Association for Bilingual Education.

Cummins, J. (2000). Language, power and pedagogy: Bilingual children in the crossfire. Clevedon, UK: Multilingual Matters.

Cummins, J. (2001). Negotiating identities: Education for empowerment in a diverse society. Ontario, CA: California Association for Bilingual Education.

Cummins, J. (2002). Language and the human spirit. TESOL Matters. Retrieved March 23, 2010, from: http:/ / iteachilearn.com/cummins/langhuman02.htm

Cummins, J., \& Sayers, D. (1995). Brave new schools: Challenging cultural illiteracy through global learning networks. New York: St. Martin's Press.

Darder, A., Torres, R., \& Gutierrez, H. (1997). Latinos and education: A critical reader. New York: Routledge.

Dei, G. (2001). Rescuing theory: Anti-racism and inclusive education. Race, Gender and Class, 8(1), 139-161.

Fishman, J.A. (1989). Language and ethnicity in minority sociolinguistic perspective. Clevedon, UK: Multilingual Matters.

Freire, P. (1994). Pedagogy of hope: Reliving pedagogy of the oppressed. New York: Continuum.

Freire, P. (1999). Pedagogy of the oppressed. New York: Continuum.

Garcia, C. (2008). Parenting Circles Project: The key conditions for the meaningful engagement of Spanish-speaking parents to support their children's school success. Unpublished manuscript, Ryerson University.

Garcia-Coll, C.T. (1990). Developmental outcome of minority infants: A process-oriented look into our beginnings. Child Development, 61(2), 270-289.

George, U., \& Michalski, J.H. (1996). A snapshot of service delivery in organizations serving immigrants, final report. Toronto, ON: University of Toronto, Centre for Applied Social Research.

Goldring, L., Berinstein, C., \& Bernhard, J.K. (2009). Institutionalizing precarious migratory status in Canada. Citizenship Studies, 13(3), 237-263.

González, N., Moll, L.C., \& Amanti, C. (Eds.). (2005). Funds of knowledge: Theorizing practice in households, communities, and classrooms. Mahwah, NJ: Erlbaum.

Hedegaard, M. (2009). Children's development from a cultural-historical approach: Children's activity in everyday local settings as foundation for their development. Mind, Culture, and Activity, 16(1), 64-82.

Klingner, J.K., \& Artiles, A.J. (2003). When should bilingual students be in special education? Educational Leadership, 61(2), 66-71.

Krashen, S. (1999). Condemned without a trial: Bogus arguments against bilingual education. Portsmouth, NH: Heinemann.

Lareau, A. (1989). Home advantage: Social class and parental intervention in elementary education. New York: Falmer.

Lerner, R.M. (1988). Personality development: A life-span perspective. In E.M. Hetherington, R.M. Lerner, \& M. Perlmutter (Eds.), Child development in life-span perspective (pp. 21-46). Hillsdale, NJ: Erlbaum.

Lerner, R.M. (1991). Changing organism-context relations as the basic process of development: A developmental contextual perspective. Developmental Psychology, 27, $27-32$.

Lo, L., Preston, V., Wang, S., Reil, K., Harvey, E., \& Siu, B. (2000). Immigrants' economic status in Toronto: Rethinking settlement and integration strategies. Working paper No. 15 . Toronto, ON: Centre of Excellence for Research on Immigration and Settlement. 
Looker, D.E. (1994). Active capital: The impact of parents on youths' educational performance and plans. In L. Erwin \& D. MacLennan (Eds.), Sociology of education in Canada (pp. 164-187). Toronto, ON: Copp Clark Longman.

Murdie, R.A., \& Teixeira, C. (2000). Towards a comfortable neighbourhood and appropriate housing: Immigrant experience in Toronto. Toronto, ON: CERIS Working Paper Series.

New London Group. (1996). A pedagogy of multiliteracies: Designing social futures. Harvard Educational Review, 66, 60-86.

$\mathrm{Ng}$, R. (1993). Racism, sexism, and nation building in Canada. In C. McCarthy \& W. Crichlow (Eds.), Race, identity and representation in education (pp. 50-59). New York: Routledge.

$\mathrm{Ng}$, R., \& Ramirez, J. (1981). Immigrant housewives in Canada. Toronto, ON: Immigrant Women's Centre.

O'Loughlin, M. (2009). The subject of childhood. New York: Peter Lang.

Onchwari, G., Onchwari, J., \& Keengwe, J. (2008). Teaching the immigrant child: Application of child development theories. Early Childhood Education Journal, 36(3), 267-273.

Organization for Economic Cooperation and Development (OECD). (2006). Where immigrant students succeed - A comparative review of performance and engagement in PISA 2003. Paris: Author. Retrieved March 23, 2010, from: www.oecd.org/dataoecd/2/38/36664934.pdf

Pacini-Ketchabaw, V., Bernhard, J.K., \& Freire, M. (2001). Struggling to preserve home language: The experiences of Latino students and families in the Canadian school system. Bilingual Research Journal, 25(1 \& 2), 115-145.

Pinkus, S. (2008). The effect of the Parenting Circles Program on home language retention and parental engagement: The case of a Spanish-speaking parent group in Toronto. Research Paper, Ryerson University.

Rogoff, B. (1990). Apprenticeship in thinking: Cognitive development in social context. New York: Oxford University Press.

Siemiatycki, M. (1998). Immigration and urban politics in Toronto. Paper presented at the third international Metropolis Conference, Israel.

Statistics Canada. (2007a). Measuring up: Canadian results of the OECD PISA study. Retrieved March 23, 2010, from: www.pisa.gc.ca/81-590-E.pdf

Statistics Canada. (2007b). Canada's national statistical agency: 2001 and 2006 Census. Retrieved March 23, 2010, from: http: / / www.statcan.ca/ menu-en.htm

Taylor, L. Bernhard, J.K., Garg, S., \& Cummins, J. (2008). Affirming plural belonging: Building on students' family-based plural and linguistic capital through a multiliteracies curriculum. Journal of Early Childhood Literacy, 8(3), 269-295.

United Nations. (2007). Global migration database. Retrieved March 23, 2010, from: http: / / www.un.org/english/

Westby, C., \& Atencio, D.J. (2002). Computers, culture and learning. Topics in Language Disorders, 22(4), 70-87. 